\title{
Article \\ Experimental Determination of the MnO Activity Coefficient in High-Manganese Slags Using the Chemical Equilibrium Method
}

\author{
Elizaveta Cheremisina ${ }^{1, *}, \mathrm{Xu} \mathrm{Gao}^{2}$, Shigeru Ueda ${ }^{3}$, Shin-ya Kitamura ${ }^{3}$, Ryo Yamashina ${ }^{4}$ and Johannes Schenk $^{5} \mathbb{D}$ \\ 1 K1-MET GmbH, 4020 Linz, Austria \\ 2 School of Metallurgical and Ecological Engineering, University of Science \& Technology Beijing, \\ Haidian Distinct, Beijing 100083, China; xgao.sme@csu.edu.cn \\ 3 Institute of Multidisciplinary Research for Advanced Materials (IMRAM), Tohoku University, \\ Sendai 980-8577, Japan; shigeru.ueda.a5@tohoku.ac.jp (S.U.); shinya.kitamura.e7@tohoku.ac.jp (S.-y.K.) \\ 4 Nippon Steel, Tokyo 102-8688, Japan; yamashina.4kn.ryoh@jp.nipponsteel.com \\ 5 Department Metallurgy, Montanuniversität Leoben, 8700 Leoben, Austria; johannes.schenk@unileoben.ac.at \\ * Correspondence: elizaveta.cheremisina@k1-met.com; Tel.: +43-680-220-0080
}

Citation: Cheremisina, E.; Gao, X.; Ueda, S.; Kitamura, S.-y.; Yamashina, R.; Schenk, J. Experimental Determination of the MnO Activity Coefficient in High-Manganese Slags Using the Chemical Equilibrium Method. Metals 2021, 11, 1190. https://doi.org/10.3390/ met11081190

Academic Editor: Alexander McLean

Received: 29 June 2021

Accepted: 22 July 2021

Published: 26 July 2021

Publisher's Note: MDPI stays neutra with regard to jurisdictional claims in published maps and institutional affiliations.

Copyright: (c) 2021 by the authors. Licensee MDPI, Basel, Switzerland. This article is an open access article distributed under the terms and conditions of the Creative Commons Attribution (CC BY) license (https:// creativecommons.org/licenses/by/ $4.0 /)$.

\begin{abstract}
The thermodynamics of manganese oxide in high-MnO-containing slags was investigated using the chemical equilibrium method in the temperature range of 1623 to $1723 \mathrm{~K}$. $\mathrm{MnO}_{-} \mathrm{SiO}_{2-}$ $\mathrm{Al}_{2} \mathrm{O}_{3}$ slags were brought into equilibrium with molten silver $(\mathrm{Ag})$ under controlled $\mathrm{CO} / \mathrm{CO}_{2}$ gas atmosphere. The equilibrium Mn concentration in the silver was measured by ICP-AES (inductively coupled plasma atomic emission spectroscopy) analysis after the experiment. Slag samples were analyzed by EPMA (electron probe microanalyzer) analysis. The obtained activity $a_{\mathrm{MnO}}$ and activity coefficient $\gamma_{\mathrm{MnO}}$ were derived as a function of the slag composition and temperature. The activity coefficient of $\mathrm{MnO}$ within the investigated slag system increased with an increasing $\mathrm{MnO} / \mathrm{SiO}_{2}$ ratio. The derived temperature dependence of the activity coefficient and partition ratio of Mn between the metal and the slag was strongly influenced by the slag composition. The thermodynamic assessment of the activity and activity coefficient of $\mathrm{MnO}$ was carried out by applying the regular solution model (RSM) on the basis of interaction energies of the cations and with FactSage ${ }^{\mathrm{TM}}$ 7.3. The theoretical calculations were compared with the experimentally derived values.
\end{abstract}

Keywords: $\mathrm{MnO}$ activity; chemical equilibrium; selective reduction; activity coefficient of $\mathrm{MnO}$; manganese distribution; regular solution model

\section{Introduction}

Manganese is an essential alloying element used during the production of high-grade steel because of its properties, and it is present in most commercially made steels. Mn reduces embrittlement caused by sulfur and improves the mechanical properties of steels, e.g., strength and hardness. Generally, Mn is added as a ferromanganese or silicomanganese alloy in the steelmaking process. Special types of steels require very low concentrations of impurities for their exceptional quality. Therefore, impurity content in the alloy, especially the phosphorus concentration, is absolutely critical, since phosphorus in steel separates at the grain boundaries and causes embrittlement [1-5].

Manganese alloys are made by reducing manganese ore composed of manganese, iron, and silicon oxides as well as phosphorus. During this reduction process, phosphorus oxides are reduced along with manganese oxides, and consequently, phosphorus is transferred into the alloy. Hence, it is necessary to decrease the P content in raw materials, i.e., in the ferromanganese or manganese ore.

Since manganese and phosphorus in steel exhibit similar thermodynamic properties, e.g., both are simultaneously oxidized, it is difficult to remove phosphorus after adding 
manganese [4,5]. There have been various studies dealing with the dephosphorization of manganese alloys and manganese ores [6-12].

Fujita et al. [6] proposed a dephosphorization method of the Mn alloy using a flux containing carbonates of basic oxides such as $\mathrm{BaCO}_{3}$. However, this method is considered fundamentally difficult and unfeasible due to many limitations.

Hils et al. [7] proposed a dephosphorization method in the early stages of an integrated process of silicomanganese alloy production. The authors suggested a process of carbon reduction and consequent separation of phosphorus into the metal phase from a mixture of manganese ore and iron ore. It was reported that the phosphorus concentration in the manganese alloy had decreased by orders of magnitude, which makes the abovementioned method feasible and applicable to the current process.

In addition to the dephosphorization of manganese ore, there are many findings on the separation of phosphorus and manganese from steelmaking slag, and many of the techniques are fundamentally common to those applied to manganese ore.

Shin et al. [8] proposed a process of selective separation of phosphorus and manganese in steelmaking slag by carbon reduction using the difference in chemical stability between $\mathrm{MnO}$ and $\mathrm{P}_{2} \mathrm{O}_{5}$. At the initial stage, steelmaking slag is carbon reduced under high-temperature and low-basicity $\left(\mathrm{CaO} / \mathrm{SiO}_{2}\right)$ conditions, and only phosphorus is selectively reduced and separated into a metal phase. If the remaining high-manganeselow-phosphorus slag is reduced together with iron ore, a high-manganese-low-phosphorus alloy can be produced. It should be noted that the conditions such as slag basicity and temperature are two main influencing factors for the selective reduction of phosphorus.

Kim [9] sulfurized the steelmaking slag to produce a liquid sulfide phase-matte, without phosphorus. A high-purity Fe-Mn alloy is produced by desulfurizing the matte. This method is based on the selective separation of the manganese sulfide phase. However, sulfur is an element that has a negative effect on steel quality, so a precise desulfurization process is required. Nevertheless, this manganese-rich sulfide phase is expected to be usable as a raw material for the production of low-phosphorus manganese.

Teratoko et al. [10], Numata et al. [11], and Du [12] focused on phosphorus's property to be distributed unevenly in a specific phase in steelmaking slag, which is easily soluble in a weakly acidic aqueous solution. A selective leaching method of the phosphoruscontaining phase was proposed that consisted of immersing it in an aqueous solution. The authors reported that a high phosphorus separation rate was achieved.

Jung et al. $[13,14]$ measured the manganese distribution between the $\mathrm{CaO}-\mathrm{SiO}_{2}-\mathrm{Fe}_{\mathrm{t}} \mathrm{O}-$ $\mathrm{MnO}$ slag and liquid silver in equilibrium with solid $\mathrm{Fe}$, in the range of a $\mathrm{MnO}$ concentration up to $20 \%$. It was reported that the Mn distribution ratio between the slag and metal increased linearly with the $\mathrm{FeO}$ content. The authors also investigated the effect of $\mathrm{CaF}_{2}$, which increased the $\mathrm{MnO}$ and $\mathrm{FeO}$ activities.

Morales and Fruehan [15] measured the activity of $\mathrm{MnO}$ and $\mathrm{FeO}$ in $\mathrm{CaO}-\mathrm{SiO}_{2}-\mathrm{Fe}_{\mathrm{t}} \mathrm{O}-$ $\mathrm{MnO}-\mathrm{P}_{2} \mathrm{O}_{5}-\mathrm{MgO}$ slags with $\mathrm{MnO}$ concentrations up to $25 \%$. They reported that the activity of $\mathrm{MnO}$ showed a positive deviation from the ideal solution and increased with rising basicity, while the $\mathrm{FeO}$ activity decreased.

Ohta et al. [16] measured the $\mathrm{MnO}$ activity coefficient at $1873 \mathrm{~K}$ in a $\mathrm{MnO}-\mathrm{SiO}_{2}-\mathrm{Al}_{2} \mathrm{O}_{3}$ slag at mullite and alumina saturation using a slag-metal equilibration technique. The authors derived an iso-activity diagram where the $\mathrm{MnO}$ activity did not substantially depend on the $\mathrm{SiO}_{2} / \mathrm{Al}_{2} \mathrm{O}_{3}$ ratio, but only on the $\mathrm{MnO}$ concentration.

Woo [17] measured the $\mathrm{MnO}$ activity in an $\mathrm{MnO}-\mathrm{SiO}_{2}-\mathrm{Al}_{2} \mathrm{O}_{3}$ slag by equilibrating it with a Pt-Mn alloy and confirmed that the $\mathrm{MnO}$ activity was not influenced by the $\mathrm{SiO}_{2} / \mathrm{Al}_{2} \mathrm{O}_{3}$ ratio but increased significantly with the increasing $\mathrm{MnO}$ mole fraction above 0.5 .

While there have been many measurements of $\mathrm{MnO}$ activity conducted in steel slags under conditions relevant to the steelmaking process, such as high temperature and low $\mathrm{MnO}$ content, fewer studies have focused on high-MnO slags containing more than $30 \%$ $\mathrm{MnO}$ and conditions applicable to the selective reduction process of $\mathrm{Mn}$ ore. According to 
the work of Shin [8], in the process of the carbon reduction of manganese ore, phosphorus oxide is easily reduced in the strongly reducing atmosphere and can then be removed from the slag phase. However, the optimal conditions for suppressing manganese reduction require further investigation. Moreover, thermodynamic knowledge of manganese behavior in high manganese slag under carbothermic reduction process conditions is insufficient, and the influence of temperature requires more examination [18].

The present study investigates the optimal slag composition and conditions for manganese reduction control in the slag phase during selective reduction. $\mathrm{MnO}$ activity was measured in $\mathrm{MnO}-\mathrm{SiO}_{2}-\mathrm{Al}_{2} \mathrm{O}_{3}$ ternary slags at different temperatures to predict the manganese distribution ratio based on the activity value of the $\mathrm{MnO}$. The results derived serve to better understand the thermodynamic properties and behavior of $\mathrm{Mn}$ in highmanganese slags.

\section{Materials and Methods}

\subsection{Principles of $\mathrm{MnO}$ Activity Measurement}

The chemical equilibrium method was applied to measure the $\mathrm{MnO}$ activity in the ternary $\mathrm{MnO}-\mathrm{SiO}_{2}-\mathrm{Al}_{2} \mathrm{O}_{3}$ slag by equilibrating it with molten silver. The equilibrium is governed by Equation (1):

$$
\mathrm{Mn}_{(\mathrm{l})}+\frac{1}{2} \mathrm{O}_{2(\mathrm{~g})}=\mathrm{MnO}_{(\mathrm{s})}
$$

Using the equilibrium constant $K_{1}$ of the reaction (1), the $\mathrm{MnO}$ activity in the slag can be expressed as follows:

$$
a_{\mathrm{MnO}}=\gamma_{\mathrm{Mn}_{\mathrm{Ag}}} \cdot X_{\mathrm{Mn}_{\mathrm{Ag}}} \cdot P_{\mathrm{O}_{2}}^{\frac{1}{2}} \cdot K_{1}
$$

where $\gamma_{\mathrm{Mn}_{\mathrm{Ag}}}$ is the activity coefficient of manganese in silver, $X_{\mathrm{Mn}_{\mathrm{Ag}}}$ is the molar fraction of manganese in silver, and $P_{\mathrm{O}_{2}}$ is the oxygen partial pressure. All activities are based on pure substances. The manganese activity coefficient in molten silver in Equation (2) and the equilibrium constant in Equation (1) have been derived in previous studies as functions of temperature $T$ (see Equations (3) and (4)). Since the oxygen partial pressure was controlled, the activity of manganese in slag can be calculated by measuring the molar fraction of manganese in silver after the equilibrium experiment.

$$
\begin{aligned}
\log \gamma_{\mathrm{Mn}} & =-\frac{358}{T}-0.0178 \\
\log K_{1} & =\frac{21234}{T}-4.6
\end{aligned}
$$

\subsection{Apparatus and Experiment}

Slags with compositions from 1 to 6 were prepared by mixing reagent grade powders of $\mathrm{MnO}, \mathrm{SiO}_{2}$, and $\mathrm{Al}_{2} \mathrm{O}_{3}$ in a predetermined stoichiometric ratio (see Table 1). The prepared slag compositions correspond to the liquidus line plotted on the ternary diagram by FactSage ${ }^{\mathrm{TM}} 7.3$ (Thermfact/CRCT (Montreal, Canada) and GTT-Technologies (Aachen, Germany). (see Figure 1) [19]. $\mathrm{SiO}_{2}$ crucibles were used for the equilibration experiment (Fujiwara Seisakusho, Tokyo, Japan, with outer diameter $11 \mathrm{~mm}$, inner diameter $9 \mathrm{~mm}$, and height $30 \mathrm{~mm}$ ). It is assumed that the uptake from the crucible was minimal and the slag composition during the experiment did not change. The prepared slags were $\mathrm{SiO}_{2}$-saturated, and thus, $\mathrm{SiO}_{2}$ presented in excess with respect to the liquid phase, which allowed significant erosion of the crucible by the slag to be prevented.

The prepared slag samples were brought into equilibrium with metallic silver under controlled atmospheres using a $\mathrm{CO} / \mathrm{CO}_{2}$ gas mixture in the range of temperatures $1623-1723 \mathrm{~K}$. The experimental temperatures were above the melting temperature of silver, which is $1240 \mathrm{~K}$ [20]. Experiments with slags from 1 to 3 were performed at three different temperatures, while slags 4,5 , and 6 were only equilibrated at $1673 \mathrm{~K}$. The time to reach equilibrium was confirmed in a preliminary experiment and the holding time was set 
to $48 \mathrm{~h}$. The silver used was a granular sample with $99.9 \%$ purity. The $\mathrm{SiO}_{2}$ crucible containing $2 \mathrm{~g}$ of slag sample and $5 \mathrm{~g}$ of metallic silver was placed into an $\mathrm{Al}_{2} \mathrm{O}_{3}$ protection crucible (Nikkato, Osaka, Japan, outer diameter $38 \mathrm{~mm}$, height $45 \mathrm{~mm}$ ) and introduced into the vertical electric resistance furnace (NEMS, BE1700T, Saitama, Japan). The sample was then heated up to the desired temperature under Ar gas atmosphere first, and after reaching the target temperature, the $\mathrm{CO} / \mathrm{CO}_{2}$ gas mixture was switched on, starting the equilibration at this point. The experimental apparatus is shown schematically in Figure 2. The furnace setup comprises a molybdenum disilicide heating element, a reaction tube (Nikkato, Osaka, Japan, outer diameter $50 \mathrm{~mm}$, inner diameter $42 \mathrm{~mm}$, length $1000 \mathrm{~mm}$ ), a thermocouple that was connected to the furnace body, and a PID (proportional integral derivative) controller (Toei Kagaku Sangyo, SU12N5383-MANNNN, Sendai, Japan). In the equilibrium experiment, a precise adjustment of the temperature is critical, which is why temperature measurements were also performed before the equilibration. A thermocouple was inserted from the upper part of the reaction tube, and temperature measurements were carried out at each position. The temperature range in the hot zone of the furnace was determined to be within $\pm 3 \mathrm{~K}$.

Table 1. Slag compositions used in the equilibration experiment (mass \%).

\begin{tabular}{cccc}
\hline Slag & MnO & $\mathbf{S i O}_{\mathbf{2}}$ & $\mathbf{A l}_{\mathbf{2}} \mathbf{O}_{\mathbf{3}}$ \\
\hline 1 & 46 & 51 & 3 \\
2 & 33 & 58 & 9 \\
3 & 26 & 59 & 15 \\
4 & 49 & 46 & 5 \\
5 & 36 & 53 & 11 \\
6 & 25 & 61 & 14 \\
\hline
\end{tabular}

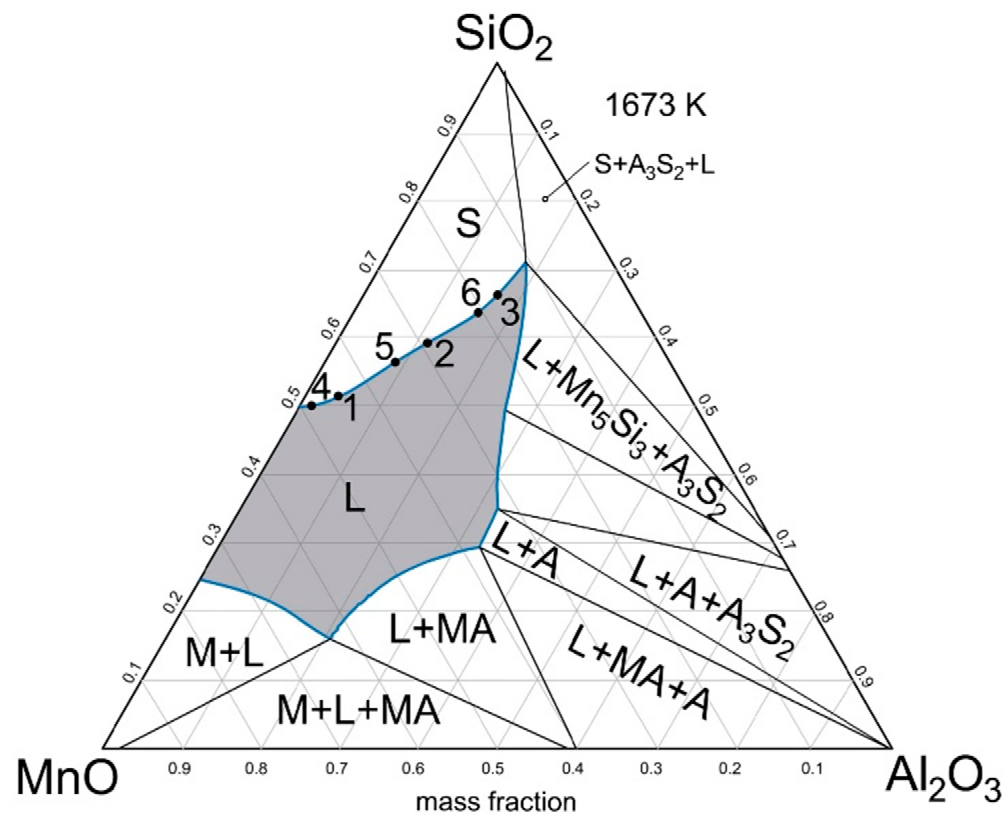

Figure 1. $\mathrm{MnO}-\mathrm{SiO}_{2}-\mathrm{Al}_{2} \mathrm{O}_{3}$ phase diagram showing slag compositions and the liquidus line at $1673 \mathrm{~K}$ calculated by FactSage ${ }^{\mathrm{TM}} 7.3$, (L-liquid slag, M-monoxide, MA—spinel, A-corundum, $\mathrm{A}_{3} \mathrm{~S}_{2}$-mullite, S—cristobalite) [19].

The partial pressure of oxygen $\left(P_{\mathrm{O}_{2}}\right)$ in the furnace was kept constant at $10^{-12}$ by controlling the mixing ratio of the $\mathrm{CO}$ and $\mathrm{CO}_{2}$ gases during the experiment. The following equilibrium reaction between gases is considered for the determination of the oxygen partial pressure [21]:

$$
\mathrm{CO}_{(\mathrm{g})}+\frac{1}{2} \mathrm{O}_{2(\mathrm{~g})}=\mathrm{CO}_{2(\mathrm{~g})}
$$




$$
\begin{gathered}
\Delta G^{\circ}=-565160+172.03 T \\
\log K_{5}=\frac{14673}{T}-4.46
\end{gathered}
$$

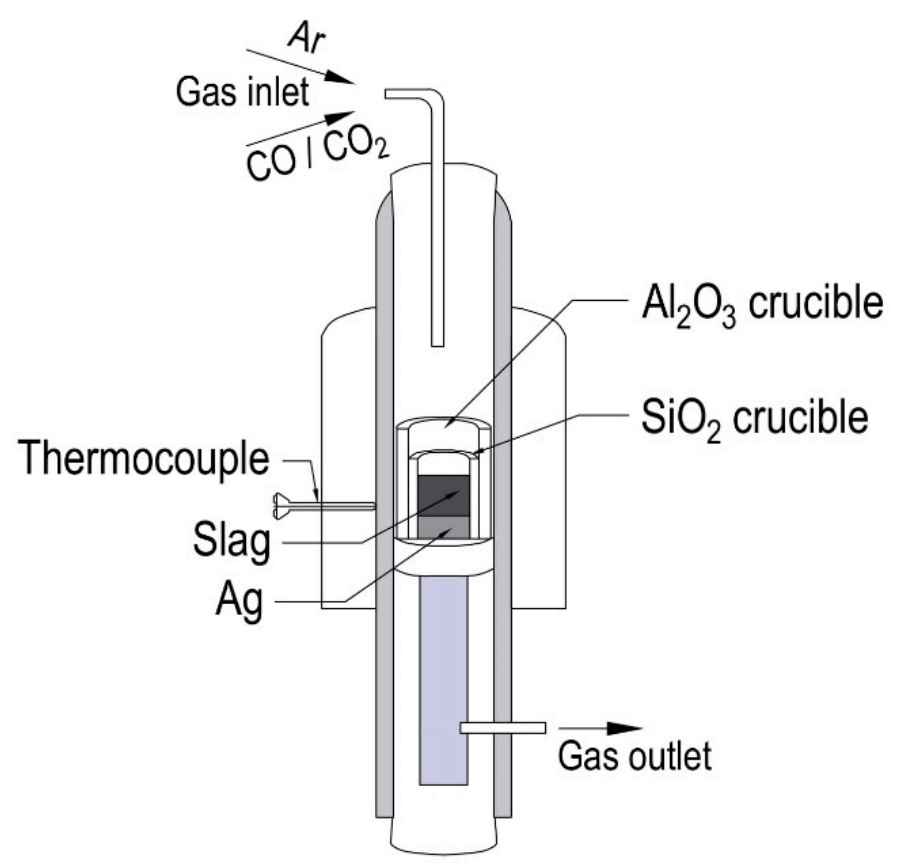

Figure 2. Schematic diagram of the experimental equipment.

The equilibrium constant $K_{5}$ of Equation (7) is expressed as follows:

$$
K_{5}=\frac{P_{\mathrm{CO}_{2}}}{P_{\mathrm{CO}} \cdot P_{\mathrm{O}_{2}}^{\frac{1}{2}}}
$$

and the oxygen partial pressure $P_{\mathrm{O}_{2}}$ is derived as follows:

$$
P_{\mathrm{O}_{2}}=\left(\frac{P_{\mathrm{CO}}}{P_{\mathrm{CO}_{2}}}\right)^{2} \cdot \frac{1}{K_{5}}
$$

During the experiment, the partial pressure ratio of the $\mathrm{CO}$ and $\mathrm{CO}_{2}$ gases was determined by means of the flow ratio mixing method. The concentration of each component of the mixed gas was obtained by controlling the flow rate of each gas. Therefore, by setting the predetermined ratio of the flow rate, the partial pressures of $\mathrm{CO}$ and $\mathrm{CO}_{2}$ gases and the oxygen partial pressure could be controlled. The gas flow was measured using a small mass flow controller (Kofloc, FCC-3000, Nagoya, Japan). A precision membrane flowmeter (HORIBA, VP-2U, Kyoto, Japan) was used to calibrate the flow measurement unit. After $48 \mathrm{~h}$, the fused slag and silver samples were quickly withdrawn from the furnace and quenched with $99.9 \%$ pure argon gas stream. The slag and metal samples were separated. Then, the slag was embedded into the resin and polished with silicone carbide water-resistant abrasive paper, with the addition of $14,000 \mu \mathrm{m}$ diamond paste. The obtained sample was supplied for the EPMA (electron probe microanalyzer) analysis performed by the (JEOL, JXA-8200, Tokyo, Japan) microanalyzer.

The silver sample was carefully cleaned from the fused slag residues and washed with ethanol. The clean Ag sample was then dissolved in strong $\mathrm{HNO}_{3}$ acid. The manganese concentration, which then came from the silver sample into the resulting solution, was measured by ICP-AES (inductively coupled plasma atomic emission spectroscopy,) 
analysis using an ICP emission spectrometer (SPECTRO ARCOS EOP system, METEK, Kleve, Germany).

\section{Results}

Equilibrium between $\mathrm{Ag}$ and the $\mathrm{MnO}-\mathrm{SiO}_{2}-\mathrm{Al}_{2} \mathrm{O}_{3}$ Slag

The Mn content in the Ag phase after equilibrium at each experimental temperature measured by ICP-AES analysis is shown in Table 2.

The compositions of the original slags from 1 to 6 (see Table 1) derived after the equilibration experiment and EPMA analysis were renamed as slag 1-a, 2-a, 3-a, etc., respectively. The analyzed compositions are shown in Table 3 and represent the average measurement result obtained from multiple points from the slag matrix, avoiding the precipitated $\mathrm{SiO}_{2}$. The images of the investigated 1-a, 2-a, and 3-a slags are shown as examples in Figure 3. It can be seen that the $\mathrm{SiO}_{2}$ phase is distributed throughout the slag matrix, as all slags were saturated with silicon dioxide.

Table 2. Mn concentrations in silver measured by ICP-AES after equilibrium in the temperature range $1623-1723 \mathrm{~K}$.

\begin{tabular}{cccc}
\hline \multirow{2}{*}{ Sample } & \multicolumn{3}{c}{ Mn in Ag, ppm } \\
\cline { 2 - 4 } & $\mathbf{1 6 7 3 ~ K}$ & $\mathbf{1 7 2 3 ~ K}$ & $\mathbf{1 6 2 3 ~ K}$ \\
\hline Slag 1 & 720.61 & 1193.85 & 1896.13 \\
\hline Slag 2 & 584.77 & 465.21 & 609.52 \\
\hline Slag 3 & 343.27 & 350.48 & 116.77 \\
\hline Slag 4 & 1150 & - & - \\
\hline Slag 5 & 850 & - & - \\
\hline Slag 6 & 350 & - & \\
\hline
\end{tabular}

Table 3. Slag and metal compositions after equilibrium.

\begin{tabular}{|c|c|c|c|c|c|c|c|c|c|c|c|c|}
\hline \multirow{2}{*}{$\begin{array}{l}\text { Slag } \\
\text { No }\end{array}$} & \multirow{2}{*}{$\mathrm{T}, \mathrm{K}$} & \multirow{2}{*}{$\begin{array}{c}\mathrm{CO}_{2} / \mathrm{CO} \\
\text { Flow } \\
\text { Ratio }\end{array}$} & \multirow{2}{*}{$\begin{array}{c}\text { Mn in } \\
\text { Ag } \\
\text { Mass \% }\end{array}$} & \multicolumn{3}{|c|}{$\begin{array}{c}\text { Slag Composition, EPMA, } \\
\text { Mass \% }\end{array}$} & \multicolumn{2}{|c|}{ Experiment } & \multicolumn{2}{|c|}{ RSM } & \multicolumn{2}{|c|}{ FactSage $^{\mathrm{TM}}$} \\
\hline & & & & $\mathrm{MnO}$ & $\mathrm{SiO}_{2}$ & $\mathrm{Al}_{2} \mathrm{O}_{3}$ & $a_{\mathrm{MnO}}$ & $\gamma_{\mathrm{MnO}}$ & $a_{\mathrm{MnO}}$ & $\gamma_{\mathrm{MnO}}$ & $a_{\mathrm{MnO}}$ & $\gamma_{\mathrm{MnO}}$ \\
\hline 1-a & \multirow{3}{*}{1673} & 0.021 & 0.072 & 48.62 & 48.00 & 3.38 & 0.105 & 0.25 & 0.161 & 0.356 & 0.130 & 0.28 \\
\hline $2-a$ & & 0.021 & 0.058 & 34.10 & 56.30 & 9.60 & 0.085 & 0.26 & 0.071 & 0.222 & 0.080 & 0.25 \\
\hline 3-a & & 0.021 & 0.034 & 25.03 & 59.33 & 15.64 & 0.050 & 0.20 & 0.040 & 0.157 & 0.040 & 0.17 \\
\hline $1-b$ & \multirow{3}{*}{1723} & 0.012 & 0.119 & 49.42 & 47.46 & 3.12 & 0.075 & 0.18 & 0.169 & 0.400 & 0.14 & 0.30 \\
\hline $2-b$ & & 0.012 & 0.047 & 33.93 & 56.91 & 9.16 & 0.029 & 0.09 & 0.081 & 0.253 & 0.087 & 0.25 \\
\hline $3-b$ & & 0.012 & 0.035 & 24.14 & 61.61 & 14.25 & 0.022 & 0.09 & 0.045 & 0.180 & 0.040 & 0.17 \\
\hline $1-\mathrm{c}$ & \multirow{3}{*}{1623} & 0.039 & 0.191 & 49.70 & 47.30 & 3.00 & 0.666 & 1.57 & 0.133 & 0.314 & 0.13 & 0.31 \\
\hline $2-\mathrm{c}$ & & 0.039 & 0.061 & 34.70 & 55.80 & 9.50 & 0.214 & 0.67 & 0.062 & 0.193 & 0.08 & 0.24 \\
\hline $3-\mathrm{c}$ & & 0.039 & 0.012 & 25.50 & 60.00 & 14.50 & 0.041 & 0.17 & 0.034 & 0.145 & 0.02 & 0.08 \\
\hline 4-a & \multirow{3}{*}{1673} & 0.021 & 0.115 & 49.00 & 47.90 & 3.10 & 0.167 & 0.37 & 0.196 & 0.431 & 0.14 & 0.31 \\
\hline 5 -а & & 0.021 & 0.085 & 38.90 & 51.50 & 9.60 & 0.123 & 0.34 & 0.121 & 0.331 & 0.10 & 0.33 \\
\hline 6-a & & 0.021 & 0.033 & 29.30 & 54.10 & 16.60 & 0.050 & 0.17 & 0.029 & 0.107 & 0.03 & 0.10 \\
\hline
\end{tabular}

Table 3 lists the measured chemical compositions of the silver phase and slags after equilibrium and the calculated values of the $\mathrm{MnO}$ activity and activity coefficients based on the experimental data, the regular solution model (RSM), and FactSage ${ }^{\mathrm{TM}}$ calculations. The concentration of components such as $\mathrm{Mn}$ in silver was considered to be sufficiently low.

The activity of manganese oxide $\mathrm{a}_{\mathrm{MnO}}$ was calculated by employing Equation (2), using the determined oxygen partial pressure and the equilibrium composition of the silver and slag phase. The activity coefficient of $\mathrm{MnO}$ was obtained by dividing the 
calculated activity value by the $\mathrm{MnO}$ mole fraction $\mathrm{X}_{\mathrm{MnO}}$ in the slag, which was derived by chemical analysis.
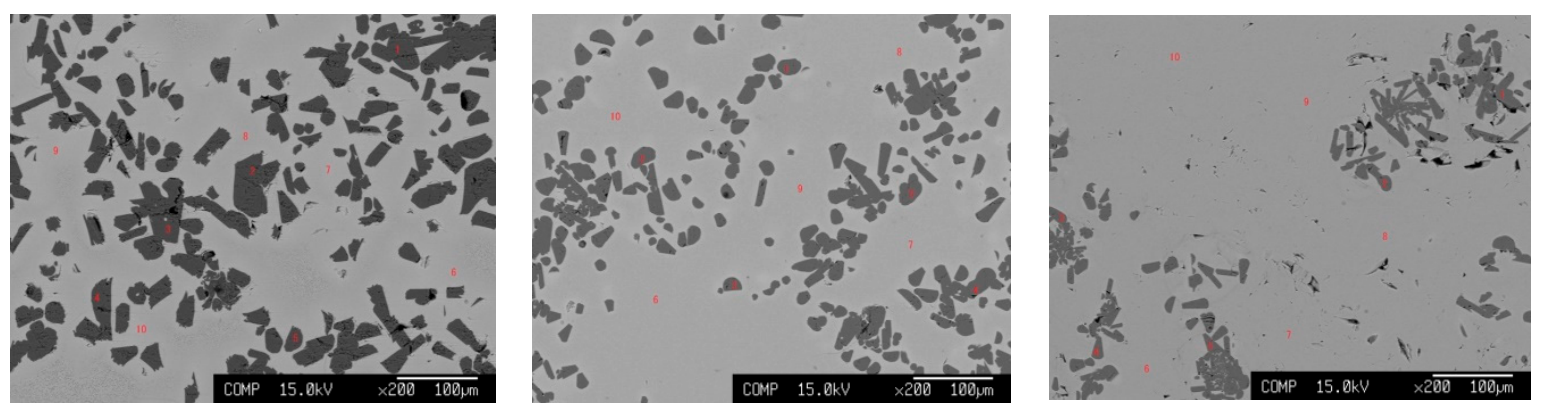

Figure 3. EPMA images of slags 1-a (left), 2-a (middle) and 3-a (right).

\section{Discussion}

According to the experimental results, in a high-manganese slag with an $\mathrm{MnO}$ concentration of about $49 \%$, the $\mathrm{MnO}$ activity value was 0.1 at $1673 \mathrm{~K}$. A decrease in the $\mathrm{MnO}$ concentration led to a drop in the $\mathrm{MnO}$ activity values. This trend is shown in Figure 4, where the activity of the $\mathrm{MnO}$ is plotted against the $\mathrm{MnO}$ mole fraction in the slag at each temperature of the experiment. The decrease in the $\mathrm{MnO}$ concentration becomes more evident when the $\mathrm{MnO}$ mole fraction drops below 0.4. The trend agrees with the results of Woo et al., who investigated the $\mathrm{MnO}$ activity in a similar ternary $\mathrm{MnO}-\mathrm{SiO}_{2}-\mathrm{Al}_{2} \mathrm{O}_{3}$ slag at $1823 \mathrm{~K}$ [17].

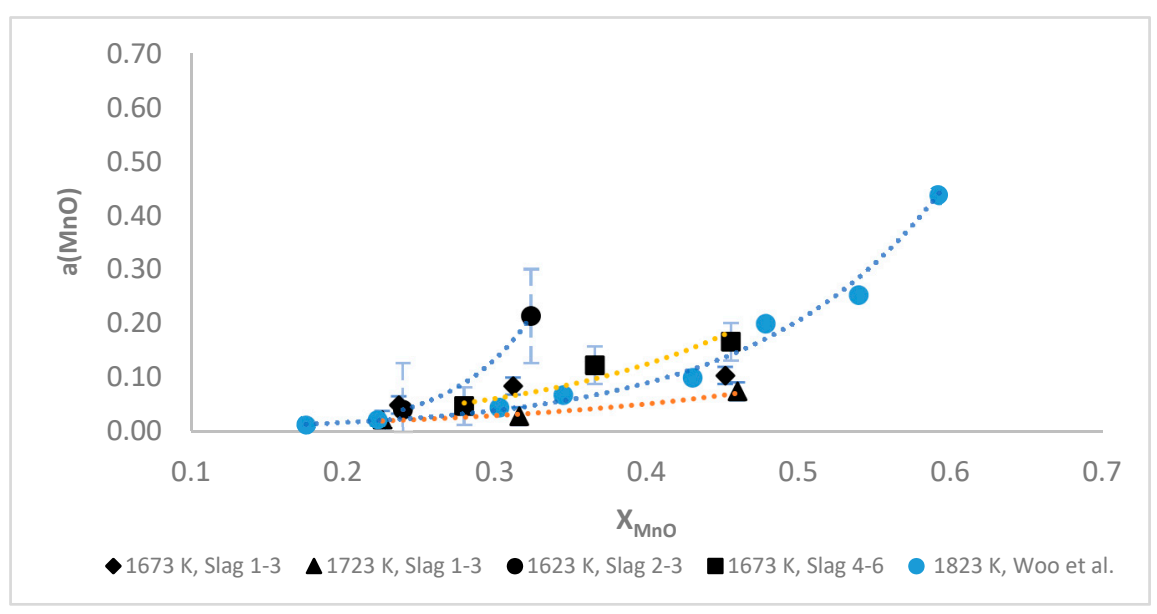

Figure 4. The dependence of the $\mathrm{MnO}$ activity on the $\mathrm{MnO}$ mole fraction. Comparison of the results obtained in this work with those of Woo et al. [17].

Figure 5 (left) depicts the effect of the $(\% \mathrm{MnO}) /\left(\% \mathrm{SiO}_{2}\right)$ ratio in the slag on the activity of the $\mathrm{MnO}$ in the temperature range of $1623-1723 \mathrm{~K}$. The values of a $(\mathrm{MnO})$ increase gradually with the increasing $(\% \mathrm{MnO}) /\left(\% \mathrm{SiO}_{2}\right)$ ratio. The effect of temperature is shown in Figure 5 (right), where the logarithms of the $\mathrm{MnO}$ activity values were plotted against the inverse temperature. As seen in the plot, the $\mathrm{MnO}$ activity decreased with temperature. Since the activity value the slag $1-\mathrm{c}$ at $1623 \mathrm{~K}$ appeared to be very high, it was neglected in the plots. In addition, the investigated slag compositions were plotted on a ternary phase diagram of the $\mathrm{MnO}-\mathrm{SiO}_{2}-\mathrm{Al}_{2} \mathrm{O}_{3}$ system, and the relationship between the $\mathrm{MnO}$ activity, activity coefficient, and slag composition at each point is shown (see Figure 6). The liquidus line on the diagram was calculated by FactSage ${ }^{\mathrm{TM}} 7.3$ at $1673 \mathrm{~K}$.

It can be seen that the rate of the decrease in the activity coefficient is moderate in comparison to the decrease in the $\mathrm{MnO}$ concentration. Based on the experimental data, the relationship between the activity coefficients of the $\mathrm{MnO}$ and the slag composition 
is presented graphically in Figure 7 (left). The activity coefficient values rise with the increasing $(\% \mathrm{MnO}) /\left(\% \mathrm{SiO}_{2}\right)$ ratio; however, the rate of the increase is sharper at the lower temperature of $1623 \mathrm{~K}$. As a next step, the derived temperature dependence for each $(\% \mathrm{MnO}) /\left(\% \mathrm{SiO}_{2}\right)$ ratio of $0.4,0.6$, and 1 was plotted in Figure 7 (right) and shows that the results vary with respect to the slag composition used.
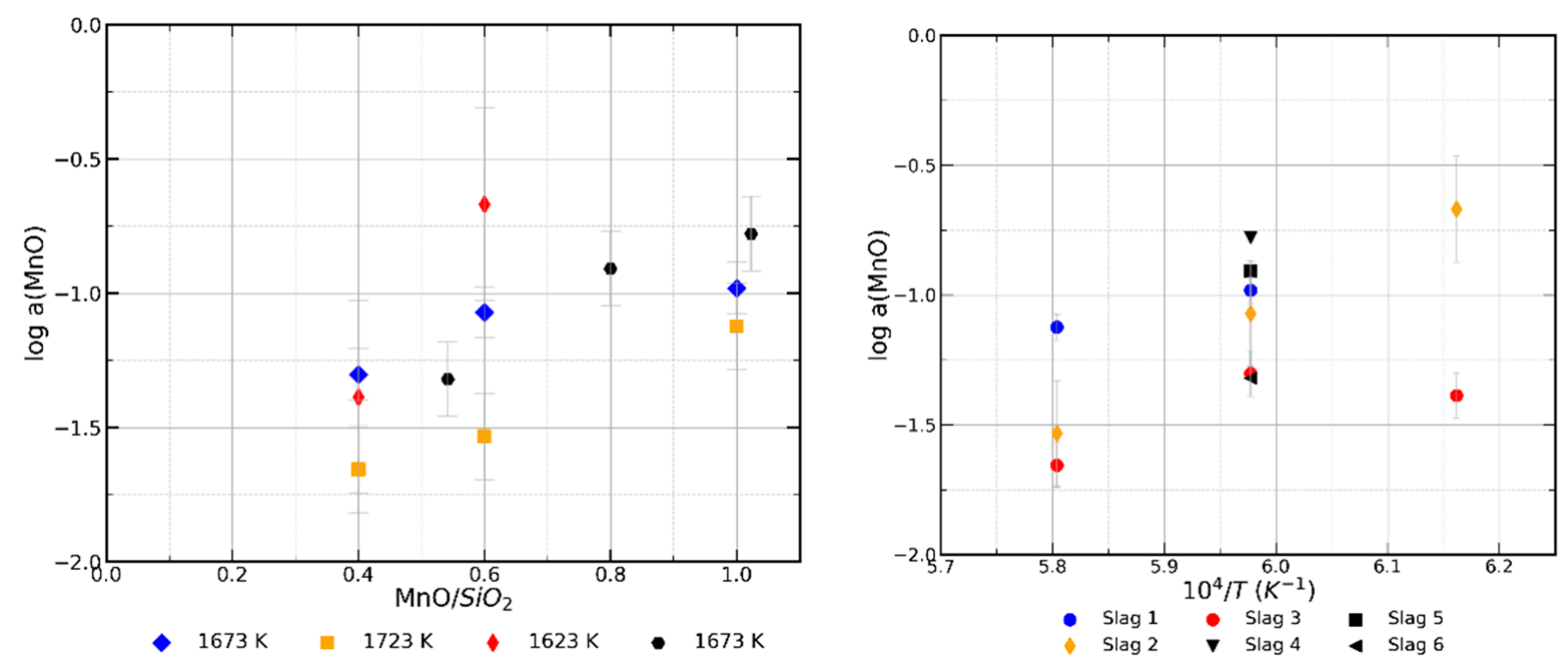

Figure 5. The relationship between the $\mathrm{MnO}$ activity of the liquid phase and the $\mathrm{MnO} / \mathrm{SiO}_{2}$ ratio at each temperature (left) and between the $\mathrm{MnO}$ activity and temperature in each slag composition (right).

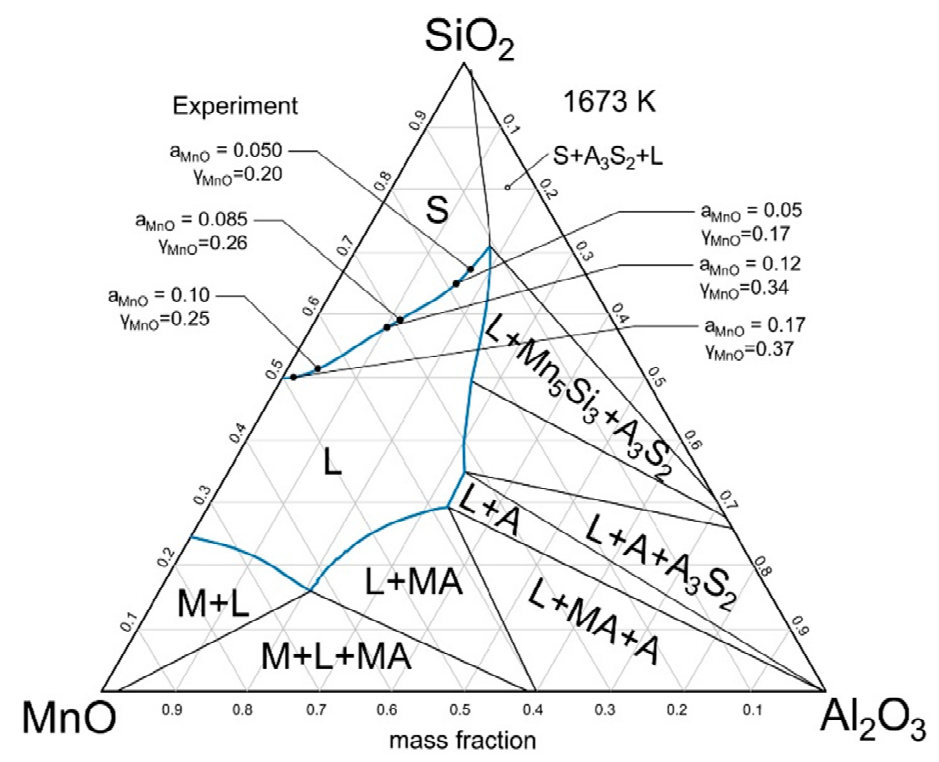

Figure 6. $\mathrm{MnO}$ activity and activity coefficient of $\mathrm{SiO}_{2}$-saturated liquid phase at $1673 \mathrm{~K}$, (L-liquid slag, $\mathrm{M}$-monoxide, $\mathrm{MA}$ - spinel, $\mathrm{A}$-corundum, $\mathrm{A}_{3} \mathrm{~S}_{2}$-mullite, S-cristobalite).

The reaction of Mn oxidation is exothermic; therefore, the equilibrium manganese distribution is expected to decrease with rising temperatures.

The manganese distribution ratio at each temperature derived from experimental data is plotted in Figure 8. A strong influence of the slag composition on the equilibrium distribution is evident.

The RSM was employed to calculate the activity and activity coefficient of $\mathrm{MnO}$ in the molten slag on the basis of interaction energies between cations and to compare with experimentally derived values.

A regular solution is a solution in which molecules are randomly arranged during mixing, but their interaction forces are not equal. Considering this, the activity coefficients 
of the slag components are calculated as a function of temperature and composition. The activity coefficient of component $i$ in a multicomponent regular solution can be derived from the following quadratic formalism [22]:

$$
R T \ln \gamma_{\mathrm{i}}=\sum_{\mathrm{j}} \alpha_{\mathrm{ij}} X_{\mathrm{j}}^{2}+\sum_{\mathrm{j}} \sum_{\mathrm{k}}\left(\alpha_{\mathrm{ij}}+\alpha_{\mathrm{ik}}-\alpha_{\mathrm{jk}}\right) X_{\mathrm{j}} X_{\mathrm{k}}+I
$$

where $R$ is the gas constant; $T$ is the temperature in Kelvin; $\alpha_{\mathrm{ij}}$ is the interaction energy between the cation of component $i$ and component $j ; X_{j}$ is the mole fraction of component $\mathrm{j}$ and $I$ is the conversion factor. Since the reference state of component $\mathrm{i}$ stands for a hypothetical liquid oxide of a regular nature in Equation (10), $\gamma_{i}$ for a real slag can be obtained using a conversion factor for the activity coefficient of a hypothetical liquid oxide, and that of a real solution in a multicomponent slag system.
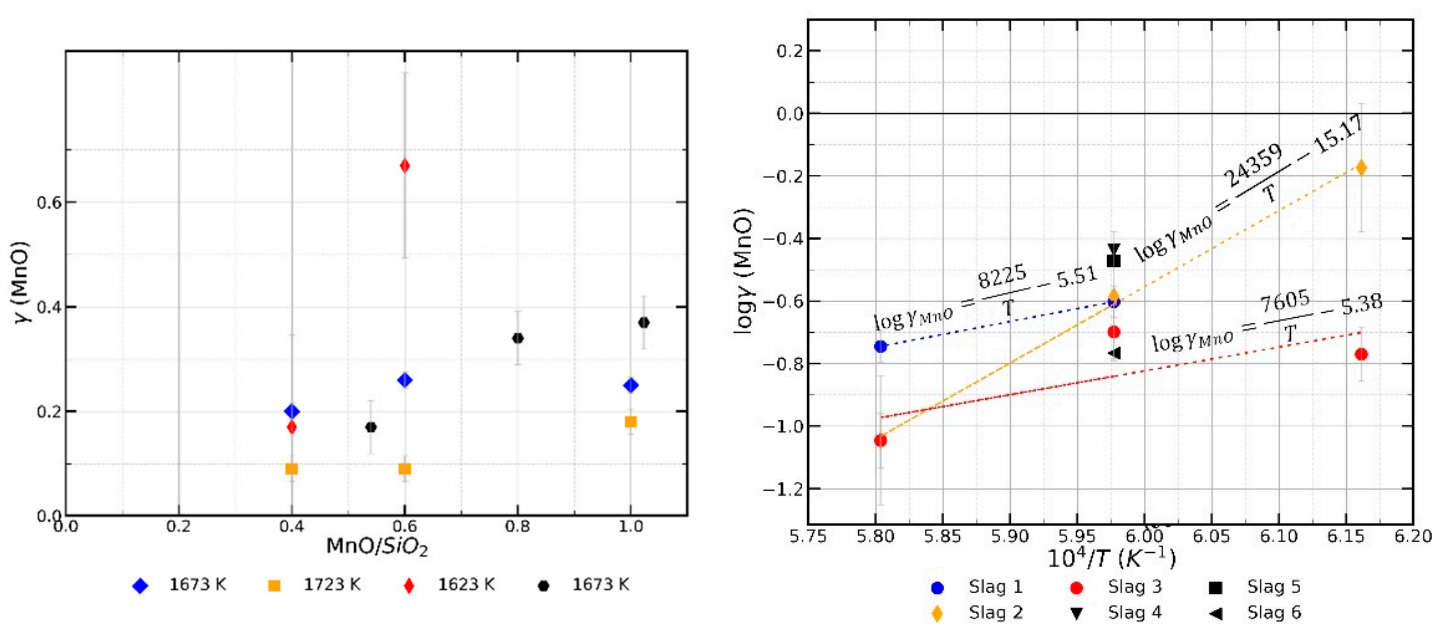

Figure 7. The relationship between the $\mathrm{MnO}$ activity coefficient and the $\mathrm{MnO} / \mathrm{SiO}_{2}$ ratio at each temperature (left) and between the $\mathrm{MnO}$ activity coefficient and temperature in each slag composition (right).

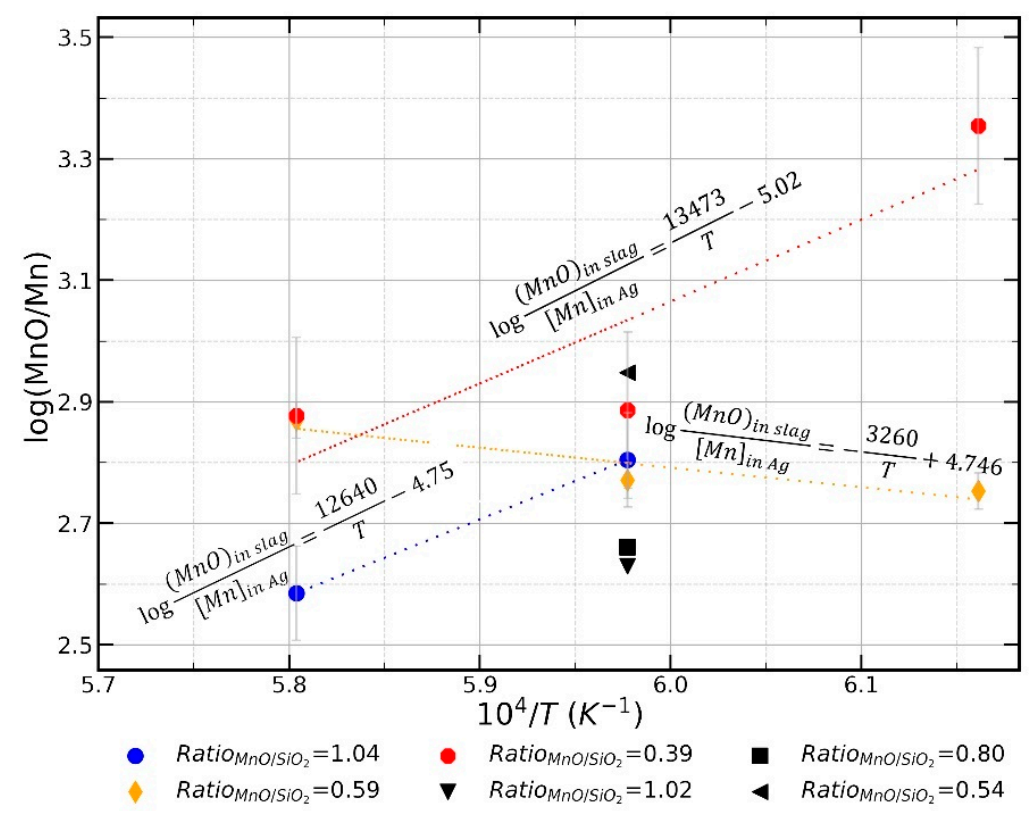

Figure 8. The relationship between $\log (\% \mathrm{MnO}) /[\% \mathrm{Mn}]$ in $\mathrm{Ag}$ and inverse temperature. 


\section{Thermodynamic Assessment of $a_{\mathrm{MnO}}$ and $\gamma_{\mathrm{MnO}}$}

The values of the interaction energies necessary for consideration in this calculation are given in Table 4. By applying Equation (10) for the currently investigated $\mathrm{MnO}-\mathrm{SiO}_{2}-\mathrm{Al}_{2} \mathrm{O}_{3}$ slag system and using the conversion factor I at $1723 \mathrm{~K}$, Equation (11) is obtained:

$$
R T \ln \gamma_{\mathrm{MnO}}=-75,310 X_{\mathrm{SiO}_{2}}^{2}-83,680 X_{\mathrm{Al}_{2} \mathrm{O}_{3}}^{2}-31,380 X_{\mathrm{SiO}_{2}} X_{\mathrm{Al}_{2} \mathrm{O}_{3}}-12,574\left(\mathrm{~J} \mathrm{~mol}^{-1}\right)
$$

Table 4. Interaction energies between cations of slag components used in the experiment (J) [22].

\begin{tabular}{cccc}
\hline Ion-ion & $\mathbf{M n}^{2+}$ & $\mathbf{S i}^{\mathbf{4 +}}$ & $\mathbf{A l}^{3+}$ \\
\hline $\mathrm{Mn}^{2+}$ & - & $-75,310$ & $-83,680$ \\
\hline $\mathrm{Si}^{4+}$ & $-75,310$ & - & $-127,610$ \\
\hline $\mathrm{Al}^{3+}$ & $-83,680$ & $-127,610$ & - \\
\hline
\end{tabular}

The results obtained using the RSM for the $\mathrm{MnO}-\mathrm{SiO}_{2}-\mathrm{Al}_{2} \mathrm{O}_{3}$ slag are listed in Table 3 . The lowest deviation between the calculated and measured values of the activity coefficients $\gamma_{\mathrm{MnO}}$ is at $1673 \mathrm{~K}$ and the activity values are generally in agreement at this temperature. However, at $1723 \mathrm{~K}$, the significant deviation between both the activities and activity coefficients is evident for low and high-MnO slags. At the lowest temperature of $1623 \mathrm{~K}$, the calculated and measured values of the activity coefficients are about 3 to 5 times different for high-MnO slags, for example, slags 1-c and 2-c, while the results agree on the low MnO-side for slag 3-c.

As the next step, the calculations were performed using the thermodynamic computation software FactSage ${ }^{\mathrm{TM}}$ 7.3. The contrast between the measured and calculated values follows the same tendency as in the case of the RSM application, e.g., at temperatures 1623 and $1732 \mathrm{~K}$. Moreover, the highest deviations are at $1623 \mathrm{~K}$ for the same slags 1-c and 2-c, while at $1673 \mathrm{~K}$, the results are for the most part in good agreement.

It can also be concluded that the calculations carried out with the RSM and FactSage TM 7.3 correspond with each other. The values of the MnO activity and activity coefficient calculated with FactSage $^{\mathrm{TM}} 7.3$ at $1673 \mathrm{~K}$ are presented graphically in Figure 9.

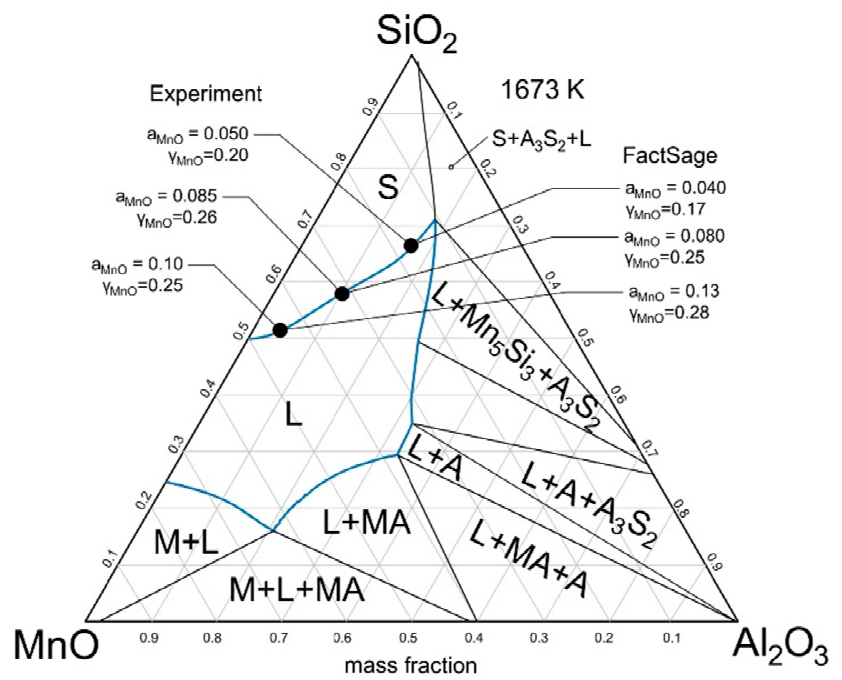

Figure 9. $\mathrm{MnO}$ activity and activity coefficient of the $\mathrm{SiO}_{2}$-saturated liquid phase at $1673 \mathrm{~K}$, (L-liquid slag, $\mathrm{M}-$ monoxide, $\mathrm{MA}$ - spinel, $\mathrm{A}$-corundum, $\mathrm{A}_{3} \mathrm{~S}_{2}$-mullite, $\mathrm{S}$-cristobalite).

Careful observation of the results suggests that the most significant contrast between the experimentally measured and calculated values (comparing with both RSM and FactSage ${ }^{\mathrm{TM}}$ ) occurs at $1623 \mathrm{~K}$, in particular where the highest activity value was derived (e.g., 0.21 for the slag 2-c). This agrees with Woo et al.'s statement that the application 
of the RSM and the conversion factor proposed by Ban-ya can only represent the system adequately for activity values below $0.15[17,22]$. Although there is scattering between the measured and calculated values of the activity coefficients, the RSM can still be used. However, not all compositional ranges can be sufficiently covered. As a result, in this case, modification of the conversion factor may be needed.

It is evident that the representation of the thermodynamic behavior of the entire real slag system covering different compositional ranges could not be conducted by applying thermodynamic models only. The combination of experimental investigation along with the thermodynamic models and FactSage ${ }^{\mathrm{TM}}$ is useful.

\section{Conclusions}

It is necessary to understand the thermodynamic properties of $\mathrm{MnO}$ in the slag for better process control during carbothermic reduction. Moreover, knowledge regarding manganese behavior is required for other metallurgical processes dealing with high-manganese slags. Thus, investigations of influencing factors such as the slag composition and temperature should be conducted. In this work, the activity and activity coefficient of $\mathrm{MnO}$ were experimentally measured in the ternary $\mathrm{MnO}-\mathrm{SiO}_{2}-\mathrm{Al}_{2} \mathrm{O}_{3}$ slag saturated with $\mathrm{SiO}_{2}$ on the basis of the equilibrium $\mathrm{Mn}$ content in the molten silver under a controlled gas atmosphere at 1623,1673 and $1723 \mathrm{~K}$. The following findings were obtained:

- The $\mathrm{MnO}$ activity values measured at $1673 \mathrm{~K}$ range from 0.05 to 0.10 and rise with the increasing $\mathrm{MnO}$ concentration from 25 to $48 \%$.

- Both the $\mathrm{MnO}$ activity and activity coefficients rise with the increasing $\mathrm{MnO} / \mathrm{SiO}_{2}$ ratio at all temperatures in the experiments.

- The $\mathrm{MnO}$ activity coefficient exhibits a tendency to decrease with temperature in all slag compositions. Based on the derived results, it was shown that the temperature dependence of the $\mathrm{MnO}$ activity coefficient differs depending on the slag composition. For each $\mathrm{MnO} / \mathrm{SiO}_{2}$ ratio, that is, $0.4,0.6$, and 1, the temperature relation was derived and presented graphically.

- For the $\mathrm{MnO}$ equilibrium distribution ratio between silver and the slag phase, the derived temperature dependence was found to be influenced by the slag composition to a great extent.

- The results show that both the temperature and the slag composition are important parameters that influenced the results.

- The thermodynamic assessment of the $\mathrm{MnO}$ activities and activity coefficients was carried out by applying the RSM and FactSage ${ }^{\text {TM }}$. Comparing the experimental results with the RSM, the values deviate from those calculated at $1623 \mathrm{~K}$ the most. The slags with the highest $\mathrm{MnO}$ activity, particularly higher than 0.15 , showed the largest scattering in activity coefficients from the model calculations. At $1673 \mathrm{~K}$, the contrast was the lowest.

- The deviation between the measured and calculated values may be due to high slag acidity with respect to the applied conversion factor, corresponding to more basic slags. In this case, the correction of a conversion factor may be needed.

- The $\mathrm{MnO}$ activity and activity coefficient values were plotted on the $\mathrm{MnO}-\mathrm{SiO}_{2}-\mathrm{Al}_{2} \mathrm{O}_{3}$ ternary diagram at $1673 \mathrm{~K}$ and compared with those calculated using FactSage ${ }^{\mathrm{TM}} 7.3$. At $1673 \mathrm{~K}$ the values generally agree, while at $1623 \mathrm{~K}$, the deviation is the greatest. The scattering between the experimental values and FactSage ${ }^{\mathrm{TM}}$ calculations follows the same trend as in the case of the RSM application. The calculated by RSM and FactSage $\mathrm{TM}$ values are in good agreement.

- The findings derived in this work contribute to a better understanding of thermodynamic properties of manganese in the $\mathrm{MnO}-\mathrm{SiO}_{2}-\mathrm{Al}_{2} \mathrm{O}_{3}$ slag and provide better process control in the metallurgical processes involving slags containing high $\mathrm{MnO}$.

Author Contributions: X.G. and R.Y. worked on the methodology and conceptualization. E.C. conducted work, calculations, and evaluation of experimental results. X.G., S.U., S.-y.K. and J.S. 
provided support in manuscript preparation. All authors have read and agreed to the published version of the manuscript.

Funding: The authors gratefully acknowledge the funding support of K1-MET GmbH, metallurgical competence center. The research program of the K1-MET competence center is supported by COMET (Competence Center for Excellent Technologies), the Austrian program for competence centers. COMET is funded by the Federal Ministry for Climate Action, Environment, Energy, Mobility, Innovation and Technology, the Federal Ministry for Digital and Economic Affairs, the Federal States of Upper Austria, Tyrol, and Styria as well as the Styrian Business Promotion Agency (SFG) and the Standortagentur Tyrol. Furthermore, Upper Austrian Research continuously supports K1-MET. Besides the public funding from COMET, the research projects are partially financed by participating scientific partners and industrial partners.

Institutional Review Board Statement: Not applicable.

Informed Consent Statement: Not applicable.

Data Availability Statement: Not applicable.

Conflicts of Interest: The authors declare no conflict of interest.

\section{References}

1. Cooman, B.C.; Chin, K.; Kim, J. High Mn TWIP Steels for Automotive Applications. In New Trends and Developments in Automotive System Engineering; Intech: Pohang, Korea, 2011; pp. 102-128. [CrossRef]

2. Ferrando, R.P.; Sanchez-Caballero, S.; Reig, M.J.; Pla, R.; Seiles, M.A.; Segue, V.J. Advanced High Strength Steel TWIP: A Door to the Future in Metal Forming. AIP Conf. Proc. 2012, 1431, 65-73. [CrossRef]

3. Wörtler, M.; Schuler, F.; Voigt, N.; Schmidt, T. Steel's Contribution to a Low-Carbon Europe 2050. Technical and Economic Analysis of the Sector $\mathrm{CO}_{2}$ Abatement Potential; Boston Consulting Group: London, UK, 2013; Volume 20.

4. Chaudhary, P.N. Dephosphorization of High Carbon Ferromanganese Using $\mathrm{BaCO}_{3}$ Based Fluxes. Ph.D. Thesis, Indian Institute of Technology, Kharagpur, India, 1999.

5. Sutou, Y.; Kamiya, N.; Umino, R.; Ohnuma, I.; Ishida, K. High-strength Fe-20Mn-Al-C-based alloys with low density. ISIJ Int. 2010, 50, 893. [CrossRef]

6. Fujita, M.; Katayama, H.; Kuwabara, M.; Saitou, C.; Ishikawa, H.; Kajioka, H. Smelting Reduction of Chrome Ore Pellet in Stirred Bath. Tetsu-to-Hagané 1988, 74, 680-687. [CrossRef]

7. Hils, G.; Newirkowez, A.; Kroker, M.; Grethe, U.; Jürgensen, R.S.; Kroos, J.; Spitzer, K.H. Conventional and tailored Mn-hearing alloying agents for the production of high manganese steels. Steel Res. Int. 2015, 86, 411-421. [CrossRef]

8. Shin, D.J.; Gao, X.; Ueda, S.; Kitamura, S.Y. Selective Reduction of Phosphorus from Manganese Ore to Produce Ferromanganese Alloy with Low Phosphorus Content. J. Sustain. Metall. 2019, 5, 362-377. [CrossRef]

9. Kim, S.J.; Shibata, H.; Kitamura, S.Y.; Yamaguchi, K. Novel technology to produce ferromanganese alloy from steelmaking slag. In Proceedings of the INFACON XIII-13th International Ferroalloys Congress: Efficient Technologies in Ferroalloy Industry, Almaty, Kazakhstan, 9-12 June 2013; pp. 655-662.

10. Teratoko, T.; Shimane, Y. Dissolution behavior of dicalcium silicate and tricalcium phosphate solid solution and other phases of steelmaking slag in aqueous solution. High Temp. Mater. Process. 2012, 31, 329. [CrossRef]

11. Numata, M.; Maruoka, N.; Kim, S.J.; Kitamura, S.-y. Fundamental Experiment to Extract Phosphorous Selectively from Steelmaking Slag by Leaching. ISIJ Int. 2014, 54, 1983-1990. [CrossRef]

12. Du, C.M.; Gao, X.; Ueda, S.; Kitamura, S.-y. A Kinetic Study on Selective Leaching of Phosphorus from Dephosphorization Slag. J. Sustain. Metall. 2020, 6, 724-738. [CrossRef]

13. Jung, S.; Kim, S.; Rhee, C.; Min, D. Thermodynamic Study on MnO Behavior in MgO-saturated Slag containing FeO. ISIJ Int. 1993, 33, 1049. [CrossRef]

14. Jung, S.; Kim, S.; Rhee, C.; Min, D. Thermodynamic properties of manganese oxide in BOF slags. ISIJ Int. 2002, 42, 63. [CrossRef]

15. Morales, A.T.; Fruehan, R.J. Thermodynamics of MnO, FeO and Phosphorus in Steelmaking Slags with High MnO contents. Metall. Mater. Trans. B 1997, 28B, 1111-1117. [CrossRef]

16. Ohta, H.; Suito, H. Activities in $\mathrm{MnO}-\mathrm{SiO}_{2}-\mathrm{Al}_{2} \mathrm{O}_{3}$ Slags and Deoxidation Equilibria of Mn and Si. Mat. Trans. B 1996, $27 B, 263$. [CrossRef]

17. Woo, D.H.; Kang, Y.B.; Lee, H.G. Thermodynamic study of $\mathrm{MnO}-\mathrm{SiO}_{2}-\mathrm{Al}_{2} \mathrm{O}_{3}$ system: Liquidus lines and activities of $\mathrm{MnO}$ at 1823 K. Metall. Mater. Trans. B 2002, 33B, 915-920. [CrossRef]

18. Yamashina, R. Measurement of MnO Activity in $\mathrm{MnO}-\mathrm{SiO}_{2}-\mathrm{Al}_{2} \mathrm{O}_{3}$ Slag. Master's Thesis, Tohoku University, IMRAM, Sendai, Japan, 2018.

19. Bale, C.W.; Bélisle, E.; Chartrand, P.; Decterov, S.A.; Eriksson, G.; Gheribi, A.E.; Hack, K.; Jung, I.H.; Kang, Y.B.; Melançon, J.; et al. FactSage Thermochemical Software and Databases, 2010-2016. Calphad 2016, 54, 189-228. [CrossRef]

20. Errandonea, D. The melting curve of ten metals up to $12 \mathrm{GPa}$ and $1600 \mathrm{~K}$. J. Appl. Phys. 2010, 108, 033517-10. [CrossRef] 
21. Fruehan, J. The Making, Shaping and Treating of Steel, Steelmaking and Refining, 11th ed.; The AISE Steel Foundation: Pittsburgh, PA, USA, 1998; Volume 2, pp. 20-767.

22. Ban-ya, S. Mathematical expression of slag-metal reactions in steelmaking. Process by quadratic formalism based on the regular solution model. ISIJ Int. 1993, 33, 2-10. [CrossRef] 